\title{
Social Enterprising Observance among B40 Urban Women for Socioeconomic Sustainability
}

\author{
Rohaiza Rokis ${ }^{\mathrm{a}}$
}

\begin{abstract}
This article explores the enterprising capabilities of economically challenged women in the urban city of Kuala Lumpur, Malaysia. The study assumes that entrepreneurial awareness and entrepreneurial intention are good predictors of women who are socioeconomically sustainable. The study sample comprises the B40 women in Kuala Lumpur, Malaysia. The B40 group refers to the "bottom 40 percent" members of the population, with a monthly household income of RM3,855 and below (USD $945^{1}$ and below). A total of 404 B40 urban women are drawn from a clustered random sample of four so-called "poor" municipal residents in Kuala Lumpur. A questionnaire survey is used to study their levels of entrepreneurial awareness and intention, administered via the Statistical Package for the Social Sciences (SPSS) Version 22. The data are analysed using descriptive statistics, ANOVA and Pearson Correlation. The findings indicate a significant relationship between their levels of entrepreneurial awareness and entrepreneurial intention with being socioeconomically sustainable. Four important indicators are deduced: 1) upholding economic justice for B40 urban women; 2) reducing urban poverty concentration among women; 3) innovating new working avenues for women homemakers in the informal work sector; and 4) enhancing moral responsibility towards sustaining the natural environment. Based on these empirical outcomes, the research also recommends a suitable approach to social entrepreneurship among women of different ethnic groups. Significantly, it will contribute to the pursuit of community development and national unity.
\end{abstract}

Keywords: B40 women, Entrepreneurial awareness, Entrepreneurial intention, Malaysia, Social enterprising, Sustainability, Urban poverty

\section{Introduction}

Poverty has been conventionally linked to the rural poor at the lower rungs of the population. However today, poverty seems to be spreading out to the urban centres as well. The rapid rural-urban migration due to industrialisation and urbanisation has led to the increase of Malaysian "urban poor". Although scholars have reasoned that those social phenomenaproduce opportunities for economic prosperity, ironically, the same phenomena also produce poverty. Bank Negara Malaysia Report (2018) states that more than $27 \%$ of the households in Kuala Lumpur earn below the living wage, i.e., RM2,000.00 (or USD500.00²) per month (https://www.theedgemarkets.com/article/urban-poorconstitute-quarter-kl-households). The cost of living is generally higher in urban areas, as food, transportation and housing are more expensive, thus causing urban poverty.

Taking gender into perspective, although the literacy rate between both sexes is almost the same, with $96.3 \%$ for women and $97.3 \%$ for men, and women's enrolment in primary and tertiary levels is higher than men, the Malaysian women's labour force

\footnotetext{
${ }^{1}$ Based on currency exchange on March 29, 2019
}

2 Based on currency exchange on March 29, 2019 
participation rate (LFPR) is only half of their male counterparts, with $54.7 \%$ as opposed to $80.1 \%$ (Malaysian Department of Statistics, 2018). This has led to the issue of poverty among women in the urban centre.

The rate of urban poor women in Malaysia may not be a serious problem yet, but might escalate into a real socio-economic problem later. The focus of this study is women in the "Bottom 40 Percent" (or B40) group, which refers to the urban poor whose monthly income is RM3,855 and below (USD945 ${ }^{3}$ and below). This article views that urban women's poverty can be reduced with their involvement in social enterprising efforts. Poor womenfolk in the urban centre, who are genuinely interested in economic activities, should not remain economically idle. Malaysia has almost $50 \%$ of women at the productive age (Malaysian Department of Statistics, 2018). Besides, Malaysia's economic agenda encourages women's involvement in the economic sector.

From the Tenth Malaysian Plan to the latest Eleventh Plan, the Malaysian Government has drawn an agenda for the upliftment of the middle-class society. The Tenth Malaysian Plan (2011-2015) (Economic Planning Unit, 2011) focused on education, information and communications technology and community- and social-based enterprises (entrepreneurship support and wealth ownership) through an investment programme. The Eleventh Malaysia Plan (2016-2020) (Economic Planning Unit, 2015) focuses on the capital economy, particularly the cost of living, household income, education and employment opportunities and entrepreneurship among the B40 households.

Based on the above, this study has two main objectives:

\subsection{Objectives}

1. to observe the social enterprising capabilities via two variables, i.e., entrepreneurial awareness and entrepreneurial intention of economically challenged women in the urban city of Kuala Lumpur, Malaysia; and

2. to identify the potential of social enterprising observance of economically challenged women in the urban city of Kuala Lumpur, Malaysia towards socioeconomic sustainability.

\subsection{Statement of the Problem}

Identifying social enterprising capabilities as a potential tool to alleviate urban poverty may be crucial for B40 Malaysian women. The Malaysia Government has initiated numerous measures, such as public services delivery, microfinancing and technological support, to encourage women to participate in social entrepreneurship Jumin, Ijab, \& Zaman, 2017). However, little emphasis has been given to its dissemination, which may have led to the underutilisation of resources (Nair \& Sagaran, 2015). Previous research has suggested that the poor attention given to penetration of urban poor women in economic activities may be rooted in the lack of concrete information (Santos, 2010), lackadaisical attitude and perception (Deb, 2016). It may also be hindered by underlying factors, such as the level of social entrepreneurial awareness and social entrepreneurial intention among this targeted group.

\footnotetext{
${ }^{3}$ Based on currency exchange on March 29, 2019
} 


\subsection{Hypothesis}

Women who have social enterprising observance (i.e., possess entrepreneurial awareness and entrepreneurial intention) can become socioeconomically sustainable.

\subsection{Research Methodology and Sampling}

A questionnaire survey was distributed to a total of 404 B40 "poor" municipal residents who were selected via clustered random sampling of these women in selected residential areas in Kuala Lumpur. The sampling frame was obtained from the federal authority i.e. Dewan Bandaraya Kuala Lumpur (DBKL). The sampling areas encompassed three villages Cheras, Bangsar and Brickfield, which are all situated in Kuala Lumpur (Ministry of Housing and Local Government Malaysia, 2017). Those villages are mostly populated by three main ethnic groups - the Malays, Chinese and Indians, respectively.

The data on the entrepreneurial awareness and intention variables were analysed using descriptive statistics, ANOVA and Pearson Correlation Coefficient and the Statistical Package for the Social Sciences (SPSS) Version 22.

This paper is organised into five main sections. The above Section 1 provides an introduction to the paper, including objectives, problem statement and also the hypothesis. Section 2 reviews key literature related to women, empowerment and entrepreneurship. A theoretical framework is outlined in Section 3 before discussing the key findings and analyses in Section 4. Section 5 concludes the article and provides some recommendations.

\section{Conceptual Framework: Social Enterprising Capabilities and Social Entrepreneurship for Economically Challenged Women in Urban Areas}

The conceptual framework of this study is based on the concepts surrounding the economically challenged women and their social enterprising and social entrepreneurship capabilities, the effects of urban poverty on them and socioeconomic sustainability.

\subsection{Social Entrepreneurial Awareness and Social Entrepreneurial Intention}

According to Tshikovhi \& Shambare (2015), social entrepreneurial awareness refers to the level of familiarity towards social entrepreneurship; while social entrepreneurial intention is the extent of the desire to become a social entrepreneur. According to Lim, Mohar, and Leilanie (2017), entrepreneurial awareness/alertness is associated with entrepreneurial intention. They also mentioned that entrepreneurial intention is the manifestation of conscious thought and awareness on entrepreneurship (2017). Furthermore, Rajendhiran and Silambarasan (2012) identified that promoting social entrepreneurial awareness is one of the major challenges to social entrepreneurs. This is aligned with a study conducted by Deb (2016) of entrepreneurs in India that lack of social entrepreneurial awareness hinders them from undertaking social entrepreneurial initiatives.

Dacul (2017) examined the influence of personality traits on the dimensions of social 
entrepreneurial intention, and found that agreeableness, openness and neuroticism, have a positive influence on certain social entrepreneurial dimensions; while extroversion has a positive influence across all dimensions of social entrepreneurship intention. Waghid and Oliver (2017) found that education plays an important role in instilling awareness and cultivating intention toward social entrepreneurship among students. However, these studies have only focused on personality traits and involved students as participants, thus excluding factors, such as culture, as mentioned by Dacin et al. (2011).

\subsection{Social Enterprising Capabilities and Social Entrepreneurship}

According to Dees (2001), social enterprising capabilities involves individuals' enterprise orientation, their social aims and social ownership. They aim for profit sharing to benefits the local community such as creating jobs, trainings or becoming intermediaries for local services, particularly in the areas of social, environmental and economic reasons.

Prior studies have recognised the significance of social enterprising capabilities having a direct connection with social entrepreneurship as shown in the existing model to reduce world poverty, especially for developing and low-income countries (Lateh, Hussain, \& Abdullah, 2018; Naminse \& Zhuang, 2018).

\subsection{Social Entrepreneurship and Women's Empowerment}

Austin, Stevenson, and Wei-Skillern (2012) defined social entrepreneurship as entrepreneurial activity with an embedded social purpose. This means that unlike business entrepreneurship which focuses on economic growth, social entrepreneurship focuses on a more holistic and sustainable approach to achieving the greater good. Rather than focusing on material gains, social entrepreneurship focuses on the goal of providing solutions and creating value in the community by using material gains as a tool to sustain changes. In addition, social entrepreneurship helps to realise the vision of "an equitable and sustainable society where people live in peace and dignity" (Pless, 2012; 8). According to El Ebrashi (2013), social entrepreneurship concerns for social development through an economically sustainable and viable model. In addition, social entrepreneurship is also a medium to find sustainable solutions to socio-economic problems through empowerment (Maguirre, Ruelas, \& Torre, 2016). These definitions are well supported by studies in several countries, such as Afghanistan (Najafizada \& Cohen, 2017); Tanzania (Mutarubukwa \& Mazana, 2017); Pakistan (Kazmi et al., 2016); and China (Naminse \& Zhuang, 2018).

Despite the impact as mentioned above, social entrepreneurship remains a debatable topic. Some have argued that social entrepreneurship merely rebrands corporate social responsibility and volunteerism (Santos, 2012). However, according to Dacin et al. (2011), the analysis of 37 definitions of social entrepreneurship reveals that the primary mission of the social entrepreneur is creating social value by providing solutions to social problems. This is seen through various models, theories and concepts which have been constructed by scholars to enrich and advance the discussion on the field of social entrepreneurship. It also indicates that this is a distinct and relevant area to be developed and studied, particularly to help in poverty reduction (Kazmi et. al., 2016).

According to Humbert (2012), although numerous studies related to social 
entrepreneurship have been conducted, studies on women's involvement in social entrepreneurship are scant. In Malaysia particularly, Md. Nor and Ramli (2016) mentioned that women's involvement in social entrepreneurship creates vibrancy in economic activities as well as enhances the family's financial stability, ultimately contributing to the nation's economy (Alam et al., 2012). Alam et al. (2012) also illustrated that social entrepreneurship enables women to escape the poverty trap.

This is a crucial issue to note as according to the United Nations (2015), women, particularly single mothers and older women, have a higher risk of poverty than men in similar types of households. This may be rooted in women's limited access to resources, exclusion from economic decision-making in households and social expectations, resulting in an increase of powerlessness among these women (Goodman, Smyth, \& Banyard, 2010). In view of the fact that the rate of urban poverty is expected to increase in Malaysia which would greatly impact the vulnerable community, such as B40 urban women (Ahmed et al., 2016), there is therefore an urgency to pay attention to this community and empower them.

Women's empowerment refers to the process of change in which a woman with a prior inability to choose, gains access to and freedom in decision-making (Kabeer, 2005). Washington and Moxley (2003) suggested that becoming empowered leads to proactiveness in resolving issues and obtaining the desired result. Lee (as cited by Washington \& Moxley, 2003) viewed women's empowerment from a socio-cognitive perspective that emphasises four elements that enable people to achieve life-changing experiences, namely self-efficacy, mastery, control and influence. Women's empowerment also involves various aspects of their life, ranging from education, health, nutrition and socio-economic status (Asaolu et al., 2018).

Although the key aspects differ among regions, women's empowerment provides benefits in various contexts and cultures, including for women from the indigenous community in Mexico (Maguirre, Ruelas, \& Torre, 2016); women in Sub-saharan Africa (Asaolu et al., 2018); and women from the marine community in Tanzania (Fröcklin, Jiddawi, \& de la Torre-Castro, 2018).

In Malaysia, women's empowerment is manifested through the efforts made to uplift the socio-economic status of women, especially those of the B40 group and who are struggling with urban poverty. Siti Ruhani, Zarina, and Bahiyah (2018) pointed out that economic empowerment among women, especially single mothers, of whom the majority are in the B40 community, is important, as in most cases, they are the heads of households.

According to Al-Dajani and Marlow (2013), social entrepreneurship helps in empowering women. To encourage women's involvement in social entrepreneurship, various kinds of assistance are provided, including microfinancing, public services delivery, grassroots innovation and technological support (Jumin, Ijab, \& Zaman, 2017). However, Alam et al. (2012) illustrated that women entrepreneurs in Malaysia struggle despite the support given by the government. Furthermore, a study by Md. Nor and Ramli (2016) which involved 50 women entrepreneurs in Penang, Malaysia, reveals that most of them rely less on government assistance in facing business-related issues, leaving an abundance of underutilised resources which were initially provided to assist women from the B40 community to improve their well-being and escape the poverty trap. Such a scenario can 
also be seen in Nigeria, where Tende (2013) argued that government credit policies have had no significant effect on the development of entrepreneurial activities there.

Connor and Bent-Goodley (2016), who explored social entrepreneurship among women in Tanzania and how their social innovations address social problems and influence the sustainability of the community, obtained contrary findings. Interviews and participant observation revealed that more government initiatives and support for entrepreneurial efforts encourage entrepreneurial involvement. This may be due to the suitability of the approach used for the targeted group as well as the level of awareness and intention regarding social entrepreneurship.

\subsection{Urban Poverty and Socio-economic Sustainability}

Urban poverty is a multidimensional phenomenon, often associated with a lack of income (Ahmed, Siwar, Bashawir, \& Mia, 2016). It is also characterised by cumulative deprivation across five major dimensions, namely income, health, education, security and empowerment (Baharoglu \& Kessides, nd., p. 124). This means that one dimension of poverty may lead to another, resulting in an individual experiencing a higher risk of being trapped in the cycle of poverty and remaining vulnerable. According to the World Bank (nd.), poverty involves two conditions, i.e.: (a) absolute poverty; and (b) relative poverty. Absolute poverty refers to the lack of resources to meet the physical and fundamental needs for survival; while relative poverty refers to a lack of resources to achieve a standard of living in the community. Both conditions appear to be major obstacles to optimising human resources for the socio-economic development of the nation.

In Malaysia, poverty measured using poverty line income (PLI), which differs between regions (i.e., Peninsular Malaysia, Sabah and Sarawak) and areas (i.e., rural and urban) due to the varied cost of living (Nair, 2010). Based on the PLI, the urban areas are known to be experiencing higher poverty than rural areas (Nurliyana, Zalmiyah, \& Rohayanti, 2017).

Ahmed et al. (2016) revealed that there is a downward trend in urban poverty in Peninsular Malaysia, indicated by the poverty rate in urban areas decreasing from 25.5 percent in 1970 to one percent in 2012. This is supported by the State of Households 2018 Report which reveals an increase in economic growth, indicated by the average household income for B40 which was 7.6 times higher in 2016 compared to 1970 (Khazanah Research Institute, 2018).

Although the economy is advancing and the poverty rate is declining, it is expected that more people could be impoverished due to the population boom, especially in the urban areas of Peninsular Malaysia, as a result of active rural-urban migration (Ahmed et al., 2016; Khazanah Research Institute, 2018). This is evinced by the growth in urban population from 27 percent in 1970 to 71 percent in 2010, with a prediction of reaching approximately 75 percent by the year 2020 (Ahmed et al., 2016). This may lead to an increase in urban poverty if appropriate actions are not taken.

The increase in urban poverty has its consequences. Although it cannot be generalised across types of urban areas due to the heterogeneity of the concept of 'urban', urban poverty has been shown to be one of the causes of social problems, such as crime, health deterioration, urban diseconomies and social issues (Ahmed et al., 2016; Hassan, 2012). It may also be indications of poor governance and inappropriate policy frameworks 
(Sijabat, 2015), which hinder the process of empowering the vulnerable B40 community.

\section{Theoretical Framework: Theory of Social Entrepreneurship and Theory of Embeddedness}

The study applies the theories of embeddedness and social entrepreneurship that are relevant to the discussion.

\subsection{Theory of Embeddedness}

The embeddedness theory clarifies how entrepreneurial conduct influences social relations (Granovetter, 1985). As indicated by this theory, individuals (i.e., women) respond and react to social relations. The theory demands that life is not centered on humans; it is centered on living organisms, which also include the socio-economic environment. The entrepreneurial experience is an exertion of empowerment by women. This study attempts to provide a new pathway for women to be economically empowered. According to Annie Roos (2018), women have to go through a process of embeddedness for a women-only entrepreneurship network within the gender structures. In her ethnographic study, she identified three processes: making proper entrepreneurs, building relationships and engaging in change, which are important in the female entrepreneurship network. Gender issues always resurface when the efforts of empowering women are discussed. The same points also appear here. The interplay between embeddedness and women may be reconstructed as female entrepreneurship networks towards the advancement of gender equality within entrepreneurship.

\subsection{Theory of Social Entrepreneurship}

This theory combines two passions: a social mission of volunteerism and compassion with a business-like discipline of innovation and determination. Owing to these dual passions, social entrepreneurship often has to exist among three common sectors: non-profit, for-profit and the government (Docherty et.al., 2009). Various research works have been undertaken on social entrepreneurship and considerable debates have occurred over the definition of social entrepreneurship. Dees (2001) provided key ideas about social entrepreneurship and highly innovative approaches to address social problems in an opportunistic, persistent and accountable manner.

Innovative approaches are typically pursued by non-profit or non-governmental organisations, but they can also be launched by for-profit or government agencies. Based on existing research on socio-organisational management, economics and strategic management, Scott Helm (2007) developed a conceptualisation of social entrepreneurship grounded in the realities of the social sector. He stated that social entrepreneurship is the catalytic behaviour of non-profit organisations that engenders value and change in the sector, community or industry through the combination of innovation, risk-taking and proactiveness.

This study thus pursues the understanding of these dual passions of a social mission and a business-like discipline that social entrepreneurship has. The situations and experiences of B40 female respondents are explored, particularly on the two variables, i.e., entrepreneurial awareness and entrepreneurial intention. This latter may lead to a better 
understanding of the potential of social enterprising observance towards socioeconomically sustainability. This is consistent with suggestions from Fakhrul et al. (2014) on the importance of overcoming poverty through social entrepreneurship.

\section{Analysis and Discussion}

To analyse the data, descriptive statistics was used. Initially the study planned to utilise inferential statistics for possible estimation and projections. However, the sampling frame provided by DBKL was too complicated for this purpose. The study then applied a quota and judgmental non-probability sampling survey of some selected residential areas in Kuala Lumpur. The analysis was conducted with the assistance of SPSS Version 22. It also applied two-way ANOVA and Pearson Correlation Coefficient. ANOVA determined whether or not there are any statistically significant differences between the means of three or more independent (unrelated) groups; while Pearson Correlation was used to test the linear relationship between two quantitative variables. Research hypothesis states that one variable affects the other in a certain way.

Most results of two-way ANOVA indicate insignificant variances among the Malays (Cheras), Chinese (Bangsar) and Indians (Brickfield). All women, regardless of ethnic groups, do not show any significant differences towards having social enterprising observance i.e. entrepreneurial awareness and interest. See Figure 1.

Figure 1: The Highlighted ANOVA Results between Three Ethnic Groups and Social Enterprising Observance

\section{Malays: \\ entrepreneurial awareness $F(2,12)=1.36, p=.421$}

Chinese:

entrepreneurial awareness $F(2,12)=1.78, p=.528$

Indians:

entrepreneurial awareness $F(2,12)=1.96, p=.635$

\begin{abstract}
Malays:
entrepreneurial intention $F(2,12)=1.57, p=.425$

Chinese:

entrepreneurial intention

$F(2,12)=1.84, p=.631$

\section{Indians:}

entrepreneurial intention $F(2,12)=2.01, p=.438$
\end{abstract}

However, results from Pearson Correlation Coefficient indicate some substantial findings, mainly that there is a significant relationship between the respondents' levels of entrepreneurial awareness and entrepreneurial intention with being socioeconomically sustainable, with values ranging from 0.5 to 0.9 . Four important indicators are deduced: 1) upholding economic justice for B40 urban women; 2) reducing urban poverty concentration among women; 3) innovating new working avenues for women homemakers in the informal work sector; and 4) enhancing moral responsibility towards sustaining the natural environment. See Figure 2. 
Figure 2: Pearson Correlation Coefficient Results of Social Enterprising Observance

1) Upholding the economic justice for B40 urban women

1.1 The respondents are interested to participate in social enterprising observance $(r=0.84)$.

1.2 They also believe that such efforts may generate a positive "return to society" $(r=0.78)$.

2) Reducing urban poverty concentration among women

2.1 The respondents are strongly interested in associating themselves with social enterprising observance by the application of socio-cultural goals $(r=0.68)$.

2.2 They also believe in positively transforming their villages by doing something worthwhile $(r=0.71)$.

3) Innovating new working avenues for women homemakers in the informal work sector

3.1 The respondents are interested in making themselves economically sustainable $(r=0.56)$.

3.2 These women believe that social enterprising observance is a pathway towards working from home $(r=0.66)$.

\section{4) Enhancing moral responsibility towards sustaining the natural environment}

4.1 The respondents strongly believe in having social observance with environmental goals $(r=0.93)$.

Despite the limitations, this study provides a basic idea of social enterprising observance among B40 women in the urban city of Kuala Lumpur. Although the two-way ANOVA results of the ethnic analyses did not indicate significant results, the Pearson Correlation Coefficient results show otherwise. For that reason, the hypothesis is partially accepted. B40 urban women of different ethnic groups possess social enterprising observance. They are aware of social entrepreneurship and have the intention to pursue it due to its positive implications, particularly through its socio-environmental components.

Based on the findings, the theories of embeddedness and social entrepreneurship are fundamental for women. These female respondents experience entrepreneurial awareness and intention, which may be exerted as an empowering factor for them to be involved in social entrepreneurship. Equipping women with entrepreneurship networks can enhance their socio-economic capability.

Moreover, the study finds that the entrepreneurial awareness and entrepreneurial intention of these female respondents are significant, which means that they are motivated toward social entrepreneurship. It also infers that the dual passions of a social mission and a business-like discipline presented by the theory of social entrepreneurship, may symbiotically work well for the B40 women. Their motivation and productive ages most certainly should not be left unattended. There may be positive socio-economic changes if they are involved in social entrepreneurship due to the positive implications of being socioeconomically sustainable.

\section{Conclusion and Recommendations}

Creating sustainable socio-economic work systems is extremely relevant and important today (Docherty, Kira and Rami Shani, 2009). The study notes that social enterprising observance is considerably significant among economically challenged women in the urban city of Kuala Lumpur, Malaysia. These women recognise the potential of being involved in social enterprise for their socioeconomic sustainability. 
Although the analysis of ethnicity does not show significant results for further analyses, it is suffice to emphasise that social enterprising capabilities and social entrepreneurship are extremely relevant today. Utilisation of social entrepreneurship as the mechanism for social change, and economic and social issues should be given utmost importance, particularly for the uplifting of the B40 women from the poverty trap.

Moreover, using a better probability sampling technique in the future to analyse the ethnic category with regards to studying women and social entrepreneurship, may lead to more significant findings. This community development aspect is extremely crucial for Malaysia's national unity.

\section{Acknowledgment}

The author conveys her gratitude to the Ministry of Education, Malaysia for providing the FRGS/1/2017/SS06/UIAM/02/3 grant. She also acknowledges the assistance of Faten Nadhirah Muhammad Fauzi for the completion of this research project.

\section{References}

Ahmed, F., Siwar, C., Bashawir, A., \& Mia, M. (2016). Urbanization and urban poverty in Malaysia: Consequences and vulnerability. Journal of Applied Sciences, 16(4), 154-160.

Alam, S., Senik, Z., \& Jani, F. (2012). An exploratory study of women entrepreneurs in Malaysia: Motivation and problems. Journal of Management Research, 4(4).

Al-Dajani, H., \& Marlow, S. (2013). Empowerment and entrepreneurship: A theoretical framework. International Journal of Entrepreneurial Behavior \& Research, 19(5), 503-524.

Asaolu, I., Alaofè, H., Gunn, J., Adu, A., Monroy, A., \& Ehiri, J. et al. (2018). Measuring women's empowerment in Sub-Saharan Africa: Exploratory and confirmatory factor analyses of the demographic and health surveys. Frontiers in Psychology, 9.

Austin, J., Stevenson, H., \& Wei-Skillern, J. (2012). Social and commercial entrepreneurship: same, different, or both?. Revista De Administracão, 47(3), 370-384.

Baharoglu, D. \& Kessides, C. (nd.). Urban Poverty. In Macroeconomics and Sectoral Approaches. pp. 124-154.

Bank Negara Malaysia. (2018). PNMB Berhad, Putrajaya.

Connor, F. R., \& Bent-Goodley, T. (2016). Zanzibari social entrepreneurs and poverty alleviation strategies: Understanding efforts to build local community sustainability. Journal of Community Practice, 24(3), 302-318.

Dacin, M., Dacin, P., \& Tracey, P. (2011). Social entrepreneurship: A critique and future directions. Organization Science, 22(5), 1203-1213.

Dacul, M. A. (2017). Working paper: The influence of personality traits on social entrepreneurship intentions of Filipino entrepreneurial students. Centre of Business Research and Development, Manila.

Deb, R. (2016). Social entrepreneurship in Assam - Drivers and roadblocks. International Journal of Transformation in Business Management, 6(1), 30-42. Retrieved from http://www.ijtbm.com

Docherty, P., Kira, M. \& Rami Shani, A.B. Eds. (2009). Creating sustainable work systems. London and New York: Routledge

Economic Planning Unit. (2015). Malaysia eleventh plan, 2016-2020, PNMB Berhad, Putrajaya.

Economic Planning Unit. (2011). Malaysia tenth plan, 2011-2015, PNMB Berhad, Putrajaya.

Edmund Terence Gomez and Johan Saravanamuttu. (2013). The new economic policy in Malaysia: Affirmative action, ethnic inequalities and social justice. Singapore: NUS Press, ISEAS Publishing, and Strategic Information and Research Development Centre

El Ebrashi, R. (2013). Social entrepreneurship theory and sustainable social impact. Social Responsibility Journal, 9(2), 188-209. 
Fakhrul Anwar Zainol, Wan Norhayate Wan Daud, Zulhamri Abdullah \& Mohd Rafi Yaacob. (2014). Overcoming poverty through social entrepreneurship: A conceptual paper. International Business Research. Vol.7, No.7

Fröcklin, S., Jiddawi, N., \& de la Torre-Castro, M. (2018). Small-scale innovations in coastal communities: shell-handicraft as a way to empower women and decrease poverty. Ecology and Society, 23(2).

Goodman, L., Smyth, K., \& Banyard, V. (2010). Beyond the 50-minute hour: Increasing control, choice, and connections in the lives of low-income women. American Journal of Orthopsychiatry, 80(1), 3-11.

Granovetter, M. (1985). Economic action and social structure: The problem of embeddedness. American Journal of Sociology. No. 91; 481-510.

Humbert, A. L. (2012). Women as social entrepreneurs. TSRC: Working Paper 72, 1-16. Retrieved from https://www.birmingham.ac.uk

Helm, S. (2007). Social entrepreneurship: Defining the nonprofit behavior and creating an instrument for measurement. University of Missouri, Kansas City, ProQuest Dissertations Publishing, 2007. 3265545.

Jumin, J., Ijab, M., \& Zaman, H. (2017). An integrated social media trading platform for B40 social media entrepreneurship. Advances in Visual Informatics, 112-119.

Kabeer, N. (2005). Gender equality and women's empowerment: A critical analysis of the third millennium development goal 1. Gender \& Development, 13(1), 13-24.

Kazmi, S. A., Hashim, M., Kee, D. H., \& Khan, F. U. (2016). Social entrepreneurship and its impact on economy: In perspective of Pakistan. International Journal of Academic Research in Accounting, Finance and Management Sciences, 6(4), 161-166. Retrieved from http://hrmars.com on 13 December 2018.

Khazanah Research Institute. (2018). The state of households 2018 report: Different realities, Khazanah Research Institute, Kuala Lumpur.

Lateh, M., Hussain, M. D., \& Abdullah, M. S. (2018). Social entrepreneurship development and poverty alleviation - A literature review. MAYFEB Journal of Business and Management, 2, 1-11. Retrieved from http://www.mayfeb.com dated on 13 December 2018.

Lim, W.L., Mohar, Y., \& Leilanie, M. N. (2017). The impact of entrepreneurial alertness on entrepreneurial intention among university students in Malaysia: Theory of planned behaviour. Journal of Engineering and Applied Sciences, 12, 1409-1418.

Maguirre, M., Ruelas, G., \& Torre, C. (2016). Women empowerment through social innovation in indigenous social enterprises. RAM. Revista De Administração Mackenzie, 17(6), 164-190.

Malaysian Department of Statistics. (2018). Malaysian Gender Index (MGGI) 2017. Kuala Lumpur: National Printer

Md. Nor, Z., \& Ramli, Z. (2016). A glimpse at women entrepreneurs in Penang. Akademika, 86(02).

Ministry of Housing and Local Government Malaysia (2017). Community development and urban wellbeing report. Retrieved from http://ehome.kpkt.gov.my/index.php/pages/view/416 on 13 December 2018

Mutarubukwa, P. A., \& Mazana, M. Y. (2017). The role and process of social entrepreneurship in a developing country. Business Education Journal (BEJ), 1(3), 1-16. Retrieved from www.cbe.ac.tz/bej

Nair, S. (2010). Moving forward: Its poverty agenda challenges, dilemma and options for Malaysia. Proceedings of the Chronic Poverty Research Centre 2010 Conference, September 8-10, 2010, United Kingdom.

Nair, S., \& Sagaran, S. (2015). Poverty in Malaysia: Need for a paradigm shift. Institutions and Economies, 7(3), 95-123. Retrieved from https://ijie.um.edu.my

Najafizada, S., \& Cohen, M. (2017). Social entrepreneurship tackling poverty in Bamyan Province, Afghanistan. World Development Perspectives, 5, 24-26.

Naminse, E., \& Zhuang, J. (2018). Does farmer entrepreneurship alleviate rural poverty in China? Evidence from Guangxi Province. PLOS ONE, 13(3), e0194912.

Pless, N. (2012). Social entrepreneurship in theory and practice-An introduction. Journal of Business Ethics, 111(3), 317-320.

Rajendhiran, N. \& Silambarasan, C. (2012). Challenges in Social Entrepreneurship. International Conference on Literature, Management and Education (ICLME'2012), Manila, Nov. 17-18. Retrieved from http://psrcentre.org dated on 13 December 2018.

Roos, A. (2018). Embeddedness in Context: Understanding Gender in a Female Entrepreneurship Network. Entrepreneurship \& Regional Development. Vol.31, Issue 3-4; 279-292

Santos, F. (2010). A positive theory of social entrepreneurship. SSRN Electronic Journal.

Santos, F. (2012). A positive theory of social entrepreneurship. Journal of Business Ethics, 111(3), 335-351. 
Sijabat, R. (2015). The role of social entrepreneurship in enabling economic opportunities for the poor: A synthesis of the literature and empirical works. International Journal of Business and Social Science, 6 (11), 35-41. Retrieved at https://ijbssnet.com dated on 13 December 2018.

Siti Ruhani, M. Y., Zarina, M. N., \& Bahiyah, O. (2018). Modelling the role of financial knowledge, attitude and practices in economic empowerment of single mothers. International Journal for Studies on Children, Women, Elderly and Disabled, 3, 54-60.

Tende S. B. A. (2013). Government initiatives toward entrepreneurship development in Nigeria. Global Journal of Business Research, 8, 109-120.

Tshikovhi, N. \& Shambare, R. (2015). Entrepreneurial knowledge, personal attitudes, and entrepreneurship intentions among South African Enactus students. Problems and Perspectives in Management, 13(1), 153-158.

United Nations (2015). The world's women 2015: Trends and statistics. United Nations, Department of Economic and Social Affairs, Statistics Division, New York.

Waghid, Z. \& Oliver, H. (2017). Cultivating social entrepreneurial capacities in students through film: Implications for social entrepreneurship education. Educational Research for Social Change, 5(2), 76100.

Washington, O., \& Moxley, D. (2003). Promising group practices to empower low-income minority women coping with chemical dependency. American Journal of Orthopsychiatry, 73(1), 109-116.

World Bank. (n.d.). Poverty overview. Retrieved from www.worldbank.org. 